\title{
Isotherapic of Culex on the biological cycle of the mosquito Culex sp
}

\author{
Patrícia Aparecida Mançano Cavalca, Cintia Miranda dos Santos, Bruno Reis, \\ Carlos Moacir Bonato
}

State University of Maringá, Maringá, PR, Brazil

\begin{abstract}
Introduction: Culex is an insect of the family Culicidae. It occurs in tropical and subtropical regions. It is known as the domestic mosquito. Their larvae develop in stagnant and dirty water, with plenty of organic matter. Some species of the insect such as Culex quinquefasciatus transmit the worms (helminths) called Wuchereria bancrofti filariasis or Elephantiasis.
\end{abstract}

Aims: Thus, the objective of this work was to evaluate the effect of isotherapic of Culex on the biological cycle of this insect.

Material and Method: The experiment was conducted at the Laboratory of Plant Physiology and Homeopathy at the State University of Maringa in the period from March 26 to December 31, 2007. Fifteen larvae of Culex sp. the same stage of development (Stage I) were used in the experiment with Isopathy of Culex sp. Was added 200 microliters of the dilutions of isotherapic 3, 6, 9, 12, 18, 24 and 30cH in each flask containing $30 \mathrm{~mL}$ of water and 15 larvae of Culex sp. The control consisted of $30 \mathrm{~mL}$ of water and $200 \mathrm{~mL}$ of $5 \%$ alcohol. The flasks were covered by tissue "toule"-type to prevent the dispersal of adult insects. The dilutions were produced according to the Brazilian Homeopathic Pharmacopoeia (1987) [1]. Were determined: average number of larvae, pupae and mosquitoes during the cycle of the insect.

Results and Discussion: The presence of Culex isotherapic in the growth solution presented complex responses. Some dilution caused positive responses $(3,6,9,12$ and $18 \mathrm{cH})$ in the average number of larvae (Figure 1). Dilution $18 \mathrm{cH}$ apparently caused a protective effect, and somehow minimized the negative influence of the environment, or protect the larvae from unfavorable abiotic conditions. Dilutions 6, 18 and 24 $\mathrm{cH}$, instead, caused adverse effect on larval and pupa survival, but positive when we consider the objective of this work. There is an interesting phenomenon when evaluating the biological responses in living according to the dilution used. The alternation of rises and falls in the physiological variables as a function of dilution were observed by several authors [2-5]. It behavior is not explained by science, but it is believed to be related to the rhythmic nature movement [6,7] and also with the law of similarity occurring between dilution and the organism that receives it. Thus, the physiological function of the dilutions in the same drug are often cyclical and not linear. 


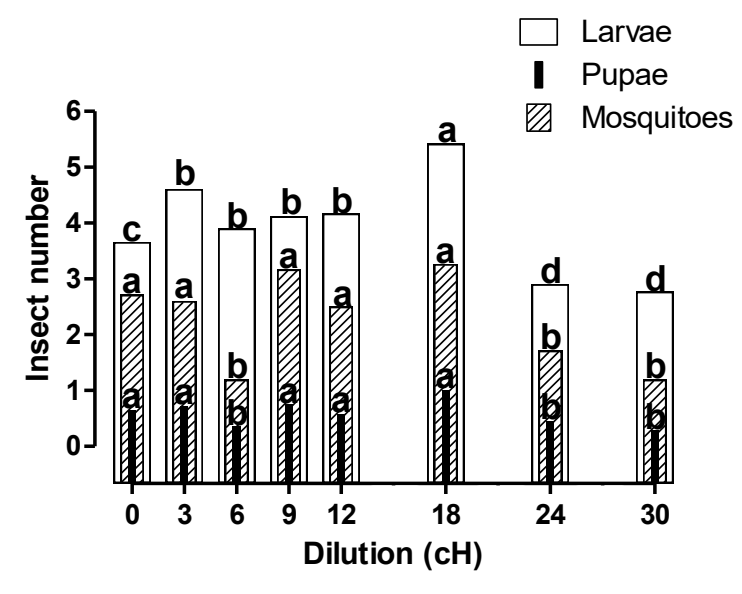

Figure 1 - Numbers of larvae, pupae and mosquitoes of Culex sp subjected to dilutions of isotherapic of Culex.

Conclusion: The results of this experiment suggest that some dilution may be used in studies to control the mosquito Culex sp.

Keywords: Diluitions, Culex sp; Elephantiasis

\section{References:}

[1] Farmacopéia Homeopática Brasileira. 1997; 4 ed. São Paulo: Atheneu. [Portuguese]

[2] Davenas, E, Beauvais F, Amara J, Oberbaum M, Robinzon B, Miadinna A, Tedeschit A, Pomeranz B, Fortner P, Belon P, Sainte-Laudy J, Poitevin B, Benveniste J. Human basophil degranulation triggered by very dilute antiserum against IgE. Nature, 1988; 333: 816-818. [English]

[3] Godou M. As potências em homeopatia: escala de dinamizações de frequencial ascendente. Revista de homeopatia. 1988; 53(3):101-105. [portuguese]

[4] Fazolin M, Estrela JLV, Argolo VM. Utilização de medicamentos homeopáticos no controle de Cerotoma tingomariannus Bechyné (Coleóptera, Chrysomelidae) em Rio branco, Acre. In: (http://lamasson.com.br/biblioteca/biblioteca/pesquisahomeopatica/embrapa.htm). Access in 28/04/00. [Portuguese]

[5] Bonato CM, Silva EP. Effect of the homeopathic solution Sulphur on the growth and productivity of radish. Acta scientiarum agronomy, 2003; 25(2): 259-263. [English]

[6] Pongratz W, Nograsek A, Endler C. Highly diluted agitated silver nitrate and wheat seedling development: effect kinetics of process of successive phases. In: Schulte J, Endler PC (eds.). Fundamental research in ultra high dilution and Homeopathy. Kluwer Academic Publishers: ordrecht, Holanda, 1998: 143-154. [English]

[7] Bonato CM. Homeopatia: mecanismo de atuação do medicamento homeopática nas plantas. In: Seminário sobre Homeopatia na agricultura orgânica. 4. 2004. Medianeira - PR. Anais... Medianeira: UFV. DFT: 2004. p. 45-48. [Portuguese] 


\section{Isoterápico de Culex sobre o ciclo biológico do mosquito Culex sp}

\section{RESUMO}

Introdução: O Culex é um inseto da família Culicidae. Ele ocorre em regiões tropicais e subtropicais. É conhecido como mosquito doméstico. Suas larvas se desenvolvem em água parada e suja, com muita matéria orgânica. Algumas espécies do inseto, como Culex quinquefasciatus transmite os vermes (helmintos) chamado Wuchereria bancrofti filiarose ou Elefantíase.

Objetivos: Assim, o objetivo deste trabalho foi avaliar o efeito do isoterápico de Culex sobre o ciclo biológico desse inseto.

Material e Método: O experimento foi conduzido no Laboratório de Homeopatia e Fisiologia Vegetal na Universidade Estadual de Maringá no período de 26 de março a 31 de dezembro de 2007. Quinze larvas de Culex sp. no mesmo estádio de desenvolvimento (Fase I) foram utilizados no experimento com Isopatia de Culex sp. Foram adicionado 200 microlitros das diluições de isoterápico 3, 6, 9, 12, 18, 24 e 30cH em cada frasco contendo $30 \mathrm{~mL}$ de água e 15 larvas de Culex sp. O controle consistiu de $30 \mathrm{~mL}$ de água e $200 \mathrm{~mL}$ de álcool de 5\%. Os frascos foram cobertos com tela anti-mosquito para evitar a dispersão dos insetos adultos. As diluições foram produzidas de acordo com a Farmacopéia Homeopática Brasileira (1987) [1]. Foram determinados o número médio de larvas, pupas e mosquitos durante o ciclo do inseto.

Resultados e Discussão: A presença do isoterápico de Culex na solução de crescimento apresentou resultados complexos. Algumas diluições provocaram respostas positivas (3, 6, 9, 12 e 18cH) no número médio de larvas (Figura 1). A diluição $18 \mathrm{cH}$ aparentemente causou um efeito protetor, e de alguma forma minimizou a influência negativa do ambiente, ou protegeu as larvas das condições abióticas desfavoráveis. As diluições 6 , 18 e $24 \mathrm{cH}$, causaram efeito adverso na sobrevivência de larvas e pupas, mas positivo quando se considera o objetivo deste trabalho. Há um fenômeno interessante ao avaliar as respostas biológicas in vivo de acordo com a diluição utilizada. A alternância de subidas e descidas nas variáveis fisiológicas em função da diluição foi observada por vários autores [2-5]. Este comportamento não é explicado ainda pela ciência, mas acredita-se estar relacionado com o movimento rítmico da natureza [6,7] e também com a lei de similitude que ocorre entre a diluição e o organismo que a recebeu. Assim, o efeito fisiológico das diluições da mesma droga são muitas vezes cíclicos e não linear.

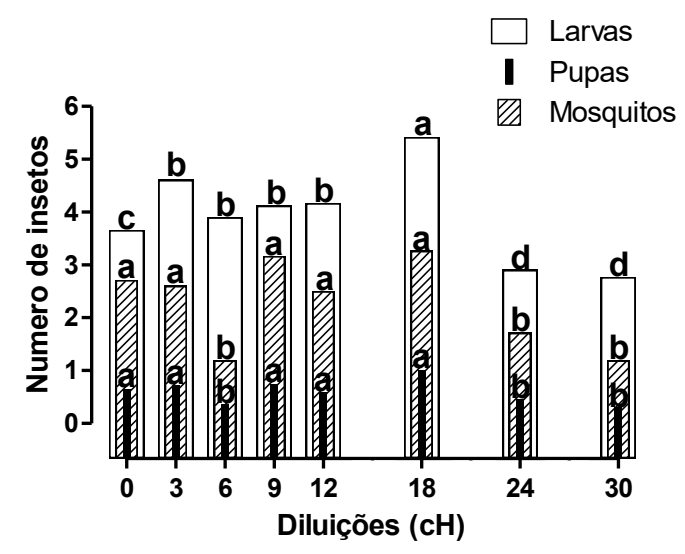

Figura 1 - Número de larvas, pupas e mosquitos de Culex sp submetidos ao isoterápico de Culex. 
Conclusões: Os resultados deste experimento sugerem que algumas destas diluições podem ser usadas em estudos para o controle do mosquito Culex sp.

Palavras-chaves: Diluições, Culex sp; Elefantiase.

\section{(c)) BY-NC-ND Licensed to GIRI}

Support: authors declare that this study received no funding

Conflict of interest: authors declare there is no conflict of interest

Correspondence author: Carlos Moacir Bonato, cmbonato@uem.br or cmbonato@hotmail.com.

How to cite this article: Cavalca PAM, dos Santos CM, Reis B, Bonato CM. Isotherapic of Culex on the biological cycle of the mosquito Culex sp. Int J High Dilution Res [online]. 2011 [cited YYYY Month dd]; 10(36): 259-262. Proceedings of the XXV GIRI Symposium and VIII CBFH; 2011 Sep 04-07; Foz do Iguaçu (Brazil). GIRI and ABFH; 2011; Available from: http://www.feg.unesp.br/ ojs/index.php/ijhdr/article/view/513/527 